\title{
Logging of Rare Rosewood and Palisandre (Dalber- gia spp.) within Marojejy National Park, Madagascar
}

Erik R. Patel

\author{
Department of Psychology \\ Cornell University \\ 211 Uris Hall, Ithaca, NY 14853, USA \\ E-mail: erp8@cornell.edu
}

\begin{abstract}
Illegal logging of precious wood has emerged as one of the most severe threats to Madagascar's northeastern rainforests. Thousands of logs, worth millions of dollars, have recently been confiscated at ports of Vohémar, Antalaha, and Toamasina. This report details the logging of rare, endemic rosewood and palisandre (Dalbergia baronii, D. louveli, and D. madagascariensis) within the eastern and northeastern portions of Marojejy National Park, Madagascar. Harvesting these heavy hardwoods is a labor intensive activity requiring coordination between local residents who manually cut the trees, but receive little profit, and a criminal network of exporters, domestic transporters, and corrupt officials who initiate the process and reap most of the profits. Structured interviews of residents identified three major perceived causes: decline in value of the local vanilla cash crop, extremely high value of rosewood, and local poverty. The impacts of such selective logging include violating local taboos as well as ecological consequences such as increased likehood of fire, invasive species, impaired habitat, and loss in genetic diversity. Recommendations include listing D. louveli under CITES Appendix III, increasing the involvement of the judicial system, no future authorizations for the gathering of precious wood, reforestation, and extensive monitoring along strategic roadways.
\end{abstract}

\section{INTRODUCTION}

Within the past few years, logging of endemic precious wood such as rosewood, palisandre and ebonies, has emerged as one of the most extensive forms of habitat disturbance within Madagascar's northeastern rainforests. Quantities of rosewood, worth millions of dollars and representing thousands of trees have recently been confiscated at the northern ports of Vohémar, Antalaha, and Toamasina (Raoel 2005; Alphonse 2007). Numerous reports have accumulated of precious wood logging within protected areas near these ports, such as Masoala National Park (Rubel et al. 2003), Marojejy National Park (Rasarely et al. 2005), and to a lesser extent Betampona Special Reserve (Kett 2005). The aim of this report is to review the conservation status of these precious woods and provide further details as to how, where, and why such logging has occurred within Marojejy National Park, a newly inaugurated World Heritage Site (IUCN 2007) where I have been working periodically since 2001. The potential long-term ecological and social consequences of such logging are discussed. Finally, recommendations are presented for discouraging this important threat to some of Madagascar's most pristine rainforests.

\section{NATURAL HISTORY}

Marojejy National Park is a conservation priority since it is known to be one of the most biologically diverse regions in Madagascar due its large elevational range; while also possessing some of the few remaining large tracts of intact lowland rainforest. The Marojejy and Andringitra massifs also possess the most well preserved montane habitats (Goodman 2000; Garreau and Manantsara 2003). Eminent botanist Dr. Henri Humbert, the first to study Marojejy's flora, considered this reserve the most impressive range in Madagascar. His 1955 book about Marojejy, entitled "A Marvel of Nature", extols the rich flora, grandeur, and pristine natural state of this park. For example, Marojejy may contain more species of forest-dwelling birds (Goodman et al. 2000), reptiles and amphibians (Raselimanana et al. 2000), as well as pteridophytes (ferns) (Rakotondrainibe 2000) than any other reserve in Madagascar. With 11 species of lemurs, including the critically endangered silky sifaka (Propithecus candidus), primate diversity is profound as well (Sterling and McFadden 2003; Duckworth et al. 1995). Several types of rare rosewood and palisandre, members of the family Leguminosae, are also found within Marojejy.

The family Leguminosae, with $80 \%$ endemism and 667 species, is amongst the largest and most unique plant families in Madagascar. It is a "large, cosmopolitan family containing many useful species, which range from major agricultural food and fodder crops, to resources of medicinal compounds and high quality hardwoods" (Du Puy 2002). Of the 100 genera of Leguminosae found in Madagascar, seven genera contain trees harvested for high quality hardwood: Albizia, Cordyla, Cynometra, Dalbergia, Dialium, Intsia, and Phylloxylon (Labat and Moat 2003). Among these, Dalbergia is perhaps the most well known and most prized as this genus contains the "rosewoods" and "palisandre" (Labat and Moat 2003; Du Puy 2002).

In Madagascar, the Tribe Dalbergieae is comprised of 43 species of Dalbergia and 2 species of Pterocarpus. All but one of the Dalbergia species (97.7\%) are endemic to Madagascar. Dalbergia species are found in all environments in Madagascar, except at high elevations above 1,600 m. In Madagascar, most Dalbergia species are shrubs though some are small to large trees (Du Puy 2002). 
Twenty-five of the Malagasy Dalbergia species are characterized by high quality, strong, and durable wood often used in expensive furniture and carpentry, but also for making oxcarts and spears. It burns well, and is therefore also a preferred wood for making charcoal and cooking. As a result of overexploitation, 9 species are now endangered (Du Puy 2002).

A recent survey and GIS analysis of Malagasy Papilionoideae (large Leguminosae subfamily) assigned IUCN Red List categories to the three Dalbergia species found within Marojejy National Park in the northeast of Madagascar (Labat and Moat 2003). Listed as "vulnerable", D. baronii and D. madagascariensis were seldom found within $5 \mathrm{~km}$ of a protected area, and the authors note that large specimens are rare due to overexploitation. Even rarer, $D$. louveli is classified as "endangered" since no trees whatsoever were found within $5 \mathrm{~km}$ of a protected area, and "populations of this rare rosewood are now severely fragmented, and it is selectively felled for the export market" (Labat and Moat 2003).

All three tree species provide precious hardwood and are harvested for furniture construction overseas, and to a far lesser degree in Madagascar. The wood of $D$. baronii and $D$. louveli is lustrous deep red and referred to as "rosewood" or "bois de rose" in French or locally in Malagasy as "Andramena" which translates to "red-trunk". D. madagascariensis is one example of palisandre, a precious Dalbergia hardwood without the vibrant red coloration (Du Puy 2002). Recently, details have become available about the illegal harvesting of palisandre and rosewood from Marojejy National Park.

\section{LOGGING}

Soon after cyclone Gafilo struck the SAVA (Sambava, Andapa, Vohémar, Antalaha) region of northeastern Madagascar in March 2004, the Ministry for the Environment, Water, and Forests (MINENVEF) issued temporary permits, valid only until the end of March, only for the collection of wood that had been toppled by recent cyclones outside of protected areas. However, these restrictions were difficult to enforce because of the remote locations of the wood and because MINENVEF agents are seldom in the field. Sylvain Velomera, former Director of Marojejy National Park, questions the justification for these initial temporary permits: "It's only a justification to allow cutting of rosewood, since cyclones do not blow over rosewood, only papaya and coconut and other small vulnerable trees, not rosewood" (pers. comm.). During this time of economic stress, post-cyclone with the price of vanilla very low, exporters encouraged local farmers to harvest rosewood, palisandre, and ebonies anywhere they could find it, including protected areas. Numerous reports of illegal precious wood logging ensued (Raoel 2005; Rasarely et al. 2005).

In response, a regional decree ( $n^{\circ} 0012005$ REG / SAV) was issued on March 25, 2005 mobilizing inspection brigades and prohibiting the traffic and transport of rosewood and ebony. Subsequently, 106 persons were arrested in northeastern Madagascar in 2005 for illegal harvesting or transport of precious wood (Rasarely et al. 2005). At Marojejy alone, in 2005 over 20 separate incidents of illegal rosewood logging are known to have occurred (Sylvain Velomora, former Director of Marojejy National Park, pers. comm.; Wul Frank, Conservation Agent, Marojejy National Park, pers. comm.). On June 1, 2005 Malagasy police confiscated 165 tons $(4,884$ logs) of ebony and 340 tons $(2,630$ logs $)$ of rosewood from two major ports in the northeast of Madagascar, Vohémar and Antalaha (Raoel 2005). More recently, in January 2007, 14 large crates of rosewood valued at about 1.5 million dollars were apprehended in Vohémar. Also, in June 2007,800 pieces of hidden rosewood were confiscated from the premises of a prominent Antalaha businessman (Nivo 2007). The wood was apparently on its way to Singapore or China which is the world's largest consumer of tropical wood (Musa 2007). SAVA regional head Paulin explained that "We do not know the companies nor the people (involved), but we can see from the documents obtained by customs officials that (it) is destined for China" (Cocks 2005).

Several lines of evidence strongly suggest that most of this confiscated wood was logged within the two largest protected areas in the region, Marojejy National Park and Masoala National Park. First of all, very little primary forest remains outside of these protected areas (IUCN 2007). It is common knowledge in the region that all precious wood outside of the protected areas has already been logged (J.C. Nadal, Mayor of Sambava. pers. comm.). Secondly, according to forest surveys by the Masoala National Park staff, $70 \%$ of locally logged rosewood occurs within Masoala National Park (Rasarely et al. 2005). Cut stumps and small stacks of cut rosewood are routinely encountered within both national parks (Rasarely et al. 2005; Sylvain Velomora, former Director of Marojejy National Park, pers. comm.; Wul Frank, Conservation Agent, Marojejy National Park, pers. comm.). Finally, numerous arrests, eyewitness accounts, and the questionnaire described in this report confirm precious wood logging within these protected areas.

From April 25 to May 15, 2005, I returned to Marojejy National Park to obtain some further information as to where, how, and why such large quantities of precious wood were harvested within this protected area. Figure 1 displays known locations of illegal rosewood and palisandre logging within the park during 2005, and was based on field reports and eyewitness sightings of actual palisandre (D. madagascariensis) and rosewood (D. baronii, D. louveli) removal as well as recently cut stumps. The data for this map were provided by the Andapa office of Marojejy National Park. As seen in Figure 1, harvested rosewood tends to occur near large rivers at low elevations, which reflects the preference of Dalbergia for this habitat (Labat and Moat 2003) as well as the need for a waterway to transport the extremely heavy logs. Rosewood trees are known to be amongst the tallest and heaviest trees within Marojejy National Park and must be cut into pieces before transport. Figure 2 shows a small stack of cut rosewood logs near the village of Mandena, only one km from Marojejy National Park. Figure 3, taken just four km from Marojejy National Park, shows illegally cut rosewood in the act of being transferred from the Manantenina River to ground transportation. It is highly likely that these logs came out of Marojejy National Park, probably from the area called Antsahabe. There is very little, if any, rosewood growing anywhere else in the area outside the park, especially in the quantity that was being loaded on the trucks there near Manantenina (Paul Atkinson, former Marojejy National Park Peace Corps Volunteer, pers. comm.).

Illegal harvesting of precious wood within Marojejy National Park appears to be a time consuming and labor intensive activity that requires an organized labor force (Rubel et al. 2003). Since these trees are relatively rare and not used by the local farmers, the location and identification of the tree requires the assistance of a specialized "kotoala", a local resident living adjacent to the forest who is intimately familiar with the local flora and fauna, 


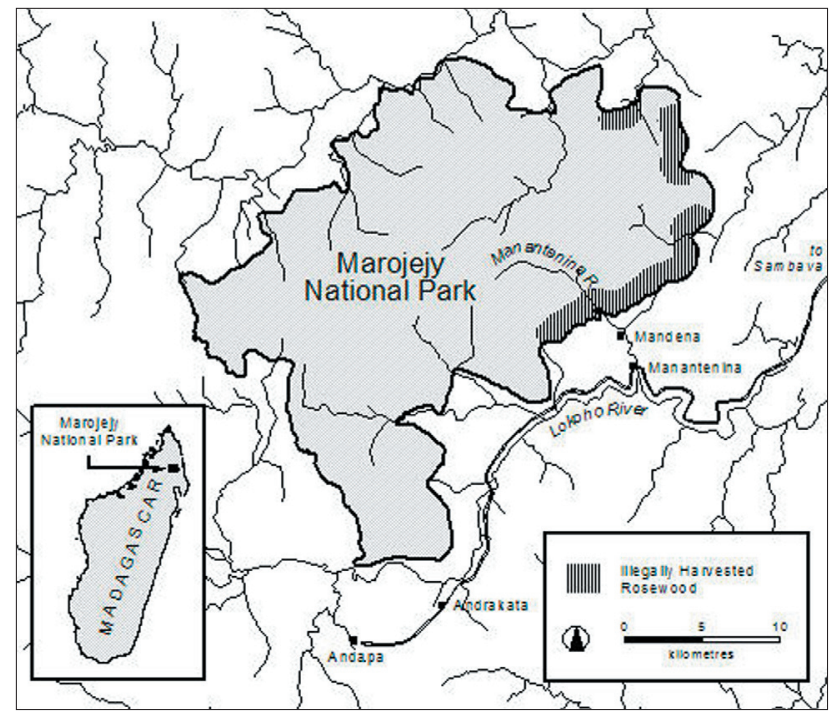

FIGURE 1. Map illustrating locations of logged rosewood within Marojejy National Park.

having harvested forest products since childhood. A recent World Bank Report has detailed the process of logging precious wood in Marojejy (Rasarely et al. 2005). Once a tree is found, it takes 1-2 hours to manually fell the tree by ax, after which it is cut into 1-2 meter lengths called "bola-bolas" that can weigh from $100 \mathrm{~kg}$ to $200 \mathrm{~kg}$ (pers. obs.; Wul Frank, Conservation Agent, Marojejy National Park, pers. comm.). One end is usually carved out in a circular fashion creating a groove around which liana are wrapped so that the wood can be dragged to a waterway (see Figure 1). Local residents are then paid only 1,000 AR per trunk (about 50 to 100 times less than retail value) to manually drag each piece out of the forest. Once all the pieces arrive at a river, they are tied together in huge bundles and floated down these waterways to ground transport (see Figure 3), and then driven to one of the major shipping ports in the region such as Vohémar and Antalaha (Sylvain Velomora, former Director of Marojejy National Park, pers. comm.; Wul Frank, Conservation Agent, Marojejy National Park, pers. comm.).

The true villains are the network of exporters, domestic transporters, and corrupt officials that organize, initiate, and greedily profit from the whole process (Rasarely et al. 2005; Rubel et al. 2003; Alphonse 2004, 2007; J.R. 2006). Most identities are unknown. But some details have come to light in the national press. One major exporter is believed to be a hotel owner in Sambava, who may be working for an Antalaha exporter. This Antalaha exporter is known to be close to an elected member of the majority party. A senator from the majority party is known to have tried to intervene to exonerate his brother who was involved in illegal rosewood exportation in SAVA (Alphonse 2007). Some customs officers and a high ranking MINENVEF official have also been implicated. In one well known example, false customs declarations were made in which a shipment of rosewood was instead declared as raffia (Alphonse 2004).

\section{LOCAL PERCEPTION OF PRECIOUS WOOD HARVESTING} To assess local residents' perceptions of the cause of this precious wood logging within Marojejy National Park, anonymous structured interviews with a single adult member of 54 different households were conducted in the villages of Mandena $(n=29)$
TABLE 1. Answers to "Why do you think there has been logging of precious wood with Parc National de Marojejy?"

\begin{tabular}{|l|l|}
\hline ANSWERS & PERCENTAGE OF RESPONDENTS \\
\hline $\begin{array}{l}\text { Decline in the Value of the Cash Crop } \\
\text { Vanilla (fell from } 230 \text { USD / kg in } 2003 \\
\text { to } 25 \text { USD / } \mathrm{kg} \text { in 2005) }\end{array}$ & $28 \%(14 / 50)$ \\
\hline $\begin{array}{l}\text { High Value of Rosewood (Worth 7 } \\
\text { USD / kg or 70-140 USD per tree) }\end{array}$ & $22 \%(11 / 50)$ \\
\hline Poverty & $20 \%(10 / 50)$ \\
\hline $\begin{array}{l}\text { Time of Year: Hunger Period (January } \\
\text { to March during cyclone season) }\end{array}$ & $8 \% \quad(4 / 50)$ \\
\hline Foreign Market & $8 \% \quad(4 / 50)$ \\
\hline Government Corruption & $6 \% \quad(4 / 50)$ \\
\hline Not Enough Staff to Patrol Park & \\
\hline
\end{tabular}

${ }^{1}$ Calvert, S. (2005). ${ }^{2}$ Rasarely et al. (2005)

and Manantenina $(n=25)$, adjacent to Marojejy National Park. Households right next to one-another were never both sampled. In total, seventy-four households were actually visited, but nine declined to participate, while in eleven other cases, no adults were available. All interviews were conducted in Malagasy. Subjects were first asked a yes / no question: "Do you think there has been logging of precious wood within Marojejy National Park?" 92.6\% (50/54) of households responded "Yes" and were then asked a second open-ended question: "Why do you think there has been logging of precious wood within Marojejy National Park?" If subjects provided more than one reason, we asked them to choose the "most important reason for logging of precious wood with Marojejy National Park". Six different responses provided by residents are displayed in Table 1. Statistically significant differences were found in the frequencies of answer categories ( $\chi^{2}=13.74 ; p<0.018$ ). A total of $70 \%$ of the respondents identified one of three major explanations: decline in value of the local vanilla cash crop ( $28 \%$ ), extremely high value of rosewood (22\%), and local poverty (20\%).

\section{ECOLOGICAL AND SOCIAL IMPACTS}

In addition to depriving the government of Madagascar of millions of dollars of taxable revenue, illegal logging of precious wood can also have severe impacts on both the forest and indigenous peoples. Although selective logging results in less absolute forest loss than clearcutting, it is often accompanied by substantial peripheral damage such as decreases in genetic diversity (Gillies 1999) and increases in the susceptibility of the impacted areas to burning (Cochrane and Schultze 1998; Cowlishaw and Dunbar 2000). Elsewhere in Madagascar, some long-term ecological consequences have been documented from polycyclic selective logging, such as the precious wood logging described in this report. Such long-term impacts include invasion of persistent, dominant non-native plant species (Brown and Gurevitch 2004), impaired faunal habitat (Ganzhorn et al. 1990), and a diminution of endemic mammalian species richness (Stephenson 1993). Dr. Frank Hawkins, Technical Director of Conservation International in Madagascar, concludes that "The secondary impacts of [precious wood] logging are much 


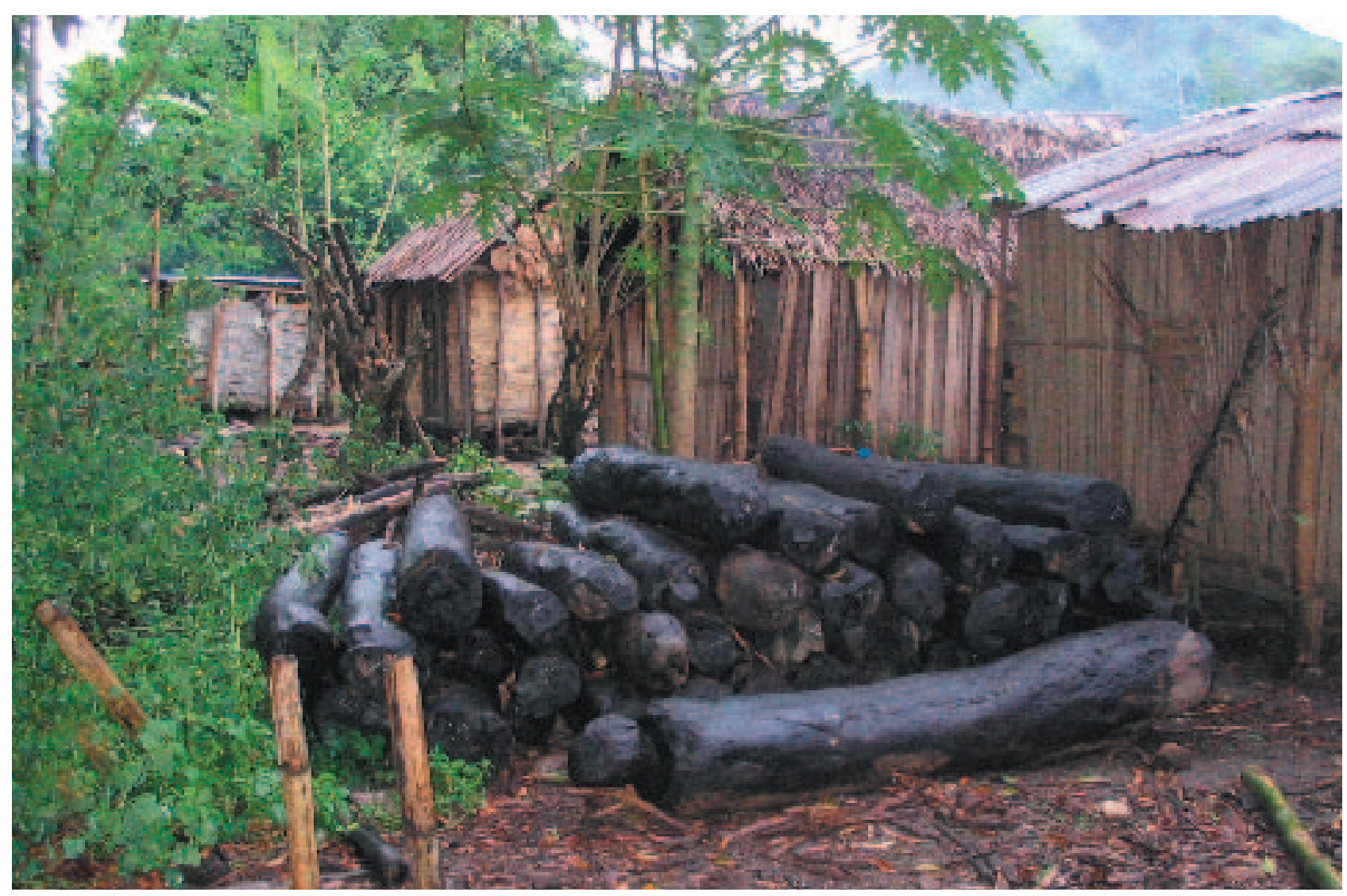

FIGURE 2. Rosewood logs cached near Mandena, 1 km from Marojejy National Park, anonymous.

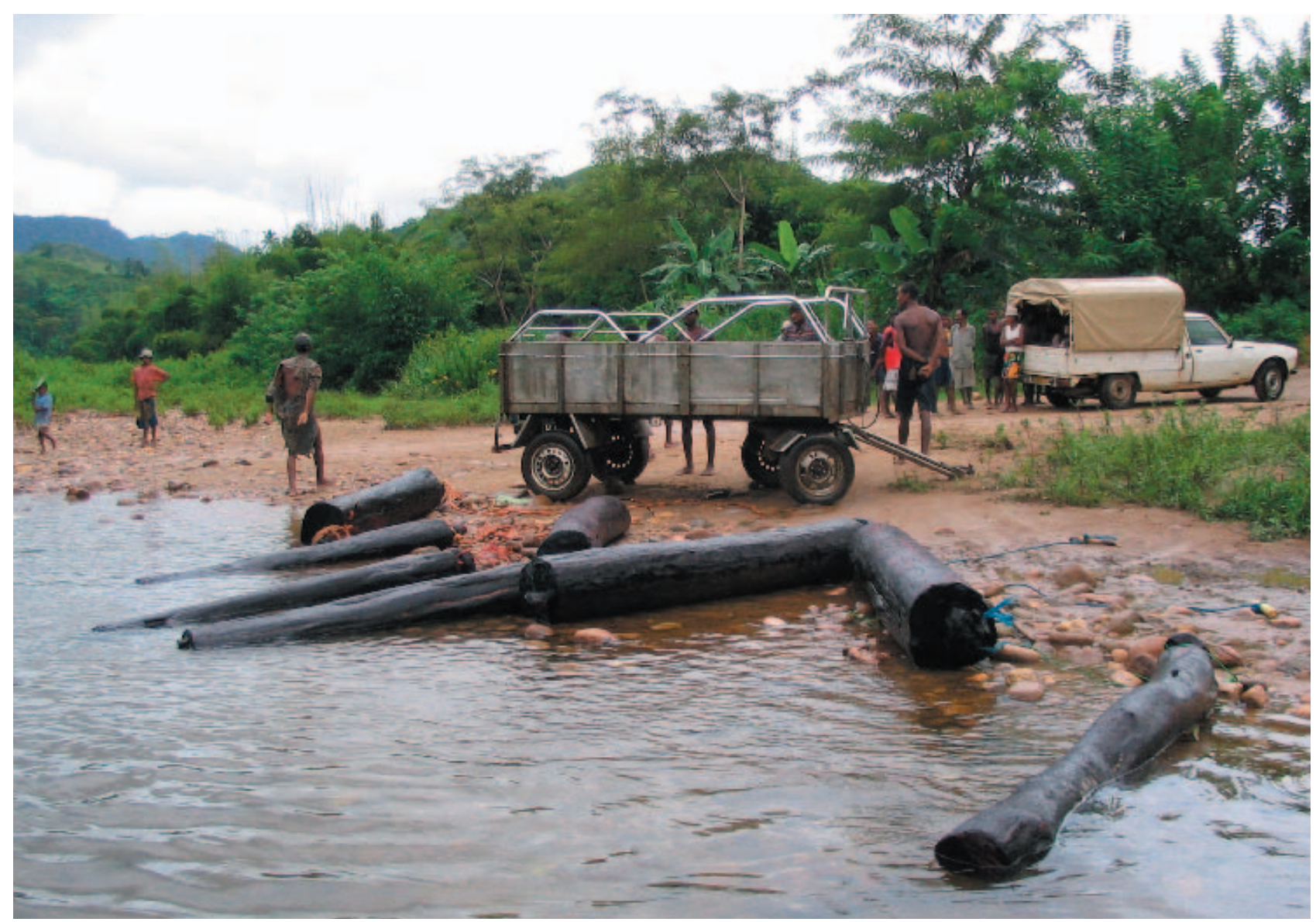

FIGURE 3. 4 km from Marojejy National Park, illegally logged rosewood being transferred from the Manantenina River to ground transport in broad daylight. March 30, 2005. 16:46, anonymous. 
more important than the logging...the forest dries out and is vulnerable to fire. People come in and hunt the animals. Very often the forest ends up disappearing completely" (Cocks 2005). Although slight habitat disturbance within Marojejy National Park has been described before (Goodman 2000; Duckworth et al. 1995), the extent of habitat disturbance due to precious wood logging described in this report far exceeds that described in these previous reports.

Precious wood logging also has angered local communities by trampling on the beliefs and taboos of local people. In traditional Sakalava culture, ebony is a sacred wood only cut by priests who conduct traditional ceremonies with ebony staffs. The chief of Ankalontany, a Sakalava Malagasy village in the northeast, explains that in 2005 "Some strangers from outside our village came here. They started cutting ebony and they clearly had no right. We asked for their authorization but they said they didn't have to show us papers. They said they had police clearance and we can't stop them." Laurent Tutu, president of the forest association of Ankalontany, remarked "It hurts us to see our trees cut like this. The forest loses its personality." (Cocks 2005).

\section{RECOMMENDATIONS AND CONCLUSIONS}

Illegal logging of precious wood continues to be a persistent source of habitat disturbance within Madagascar's northeastern rainforests. Unlike fuel-wood logging or slash-and-burn agriculture ("tavy"), the logging of precious wood is not primarily motivated by the subsistence requirements of local people. It is considered an organized criminal activity in which participating local residents receive but a tiny fraction of the profit made by the exporters, intermediaries and corrupt officials that initiate this entire process (Rasarely et al. 2005; Rubel et al. 2003; Alphonse 2004, 2007; J.R. 2006). Dr. Frank Hawkins emphasizes that "... The local people who are employed earn little money. $90 \%$ of the revenue doesn't stay in the community" (Cocks 2005). When local residents were asked about the causes of rosewood logging within Marojejy, they primarily offered economic explanations such as the high value of rosewood and local poverty. In a nation where per capita annual income averages only 255 US dollars (US AID 2005), even a very small wage, e.g. 1,000 AR per log, can be significant, particularly during a time of low vanilla prices.

Extensive international, national, and local reforms will be required to discourage future logging. As reported by respondents in this survey, the high demand and value of rosewood is at the root of this problem. Imposing international trade regulations on Malagasy precious wood could reduce demand. Currently, no Malagasy rosewood is regulated under the Convention on International Trade in Endangered Species (CITES). Brazilian rosewood (D. nigra), listed as "vulnerable" by the IUCN, is the only type of rosewood that is protected under CITES. Although D. louveli, found in Marojejy National Park, is even more endangered, it has not yet been included in the CITES Appendices. However, a 1997 CITES Tree Species Evaluation exercise did highlight $D$. louveli as meeting the criteria (unsustainability) for Appendix II (CITES 1997). Extending CITES Appendix II regulation to $D$. louveli would require exporting and importing nations to verify the timber was legally acquired and the logging not detrimental to species survival. Like big-leaf mahogany, the premier commercial timber species of Latin America, CITES may be the only way to reduce unsustainable exploitation of precious wood in Madagascar (Blundell 2004). However, also as in the case of big-leaf mahogany, enforcing these international regulations will be difficult and require a new multi-lateral, cost-effective system to determine if exported wood has met the non-detrimental and legal criteria (Blundell 2007).

Obtaining protection under CITES Appendix I or II can be a very lengthy process since it requires CITES parties to vote on a listing. It was not until 2003 that big-leaf mahogany received such protection. This was the first time in history a commonly traded timber species was voted into CITES Appendix I or II. Before big-leaf mahogany was voted into Appendix II, several nations, such as Costa Rica, Boliva, and Brazil, voluntarily listed this species under Appendix III; which can be an important precursor to gaining protection under Appendix I or II. Obtaining listing under Appendix III is a much quicker process since it is simply a voluntary act by a country. Appendix III only stipulates that a listing country show export permits verifying the legality of the shipment. Unlike Appendix I or II, it makes few demands of importers (Blundell 2004). If the government of Madagascar is truly devoted to halting illegal precious wood logging, they will list D. louveli on Appendix III.

Nationally, improving enforcement of existing laws as well as increasing the involvement of the judicial system could help discourage future precious wood logging. For violations at Masoala National Park, Rubel et al. (2003) emphasize that "Judicial involvement is very rare. When there is legal involvement, almost no convictions." When there are convictions, the fines for seized wood in the SAVA region are very low (152 AR/ kg) (Rasarely et al. 2005). Stiffer fines may not be enough. According to Alphonse (2007), the person who has the real power to dissuade future logging and increase punitive measures against the organizers is Koto Bernard, Minister of Environment, Water and Forests.

The continued assistance of local residents in reporting new incidents is crucial. It was only with the help of local people that authorities were able to apprehend a massive shipment of rosewood in Vohémar earlier this year (Alphonse 2007). Even within the newly inaugurated World Heritage Sites of Marojejy National Park and Masoala National Park, only a small staff is available to monitor these large forests (IUCN 2007). Of the 32 employees for both Marojejy National Park (60,050 ha) and Anjanaharibe - Sud Special Reserve $(32,100$ ha), only 14 go into the field, each for a few days each month (Gerard Bakharzafy, former Ecotourism Chief, Marojejy National Park, pers. comm.). Several Marojejy park agents have explained that they are responsible for too much territory, which makes it difficult for them to effectively monitor their region (Tila Augustin, Conservation Agent, Marojejy National Park, pers. comm.; Miandrasoa Simon, Conservation Agent, Marojejy National Park, pers. comm.). Rasarely et al. (2005) concur that "There is a crucial lack of personnel and budget in the local forestry service".

The most in-depth analysis of precious wood logging in the SAVA region was Rasarely et al.'s (2005) joint World Bank investigation. Three key recommendations were made. First, no future authorizations for the gathering of precious wood following cyclone damage should be issued. Second, reforestation should be promoted in all areas where logging occurred. Finally, new patrols should be established at strategic roadways, such the road between Manantenina and the entrance to Marojejy National Park, where much precious wood is known to have been transported (Sylvain Velomora, former Director of Marojejy 
National Park, pers. comm.; Wul Frank, Conservation Agent, Marojejy National Park, pers. comm.). The recent completion of two new bridges over the Manantenina River in 2007 has made motorized transportation along this road even easier. Additional patrols will also be needed along logging 'hotspots' in the more remote northern and eastern portions of the park (see Figure 1).

Preventing further precious wood logging within Marojejy National Park will be extremely difficult since it has been organized by high ranking officials and prominent businessmen who are able to act above the law (Alphonse 2004, 2007; J.R. 2006; Raserely et al. 2005). Nevertheless, there are a few rays of hope. Many, but not all Marojejy park employees implicated in rosewood logging have been terminated or transferred. According to a recent IUCN (2007) document, old clearings seem to be showing some regeneration and there has been little new agricultural encroachment. Park management is evaluated in the same document as well established, organized, and professional. Masoala National Park faces far more managerial challenges given all of its waterways and the difficulty of accessing the eastern boundary. However, land cleared for marijuana plots has recently been observed within the remote northern sector a few kilometers from the park boundary (pers. obs.). Let us hope that World Heritage status will foster the extreme vigilance required to prevent further illegal logging of precious wood. As one of the most biologically diverse and unique national parks in Madagascar (Goodman 2000), Marojejy National Park deserves our attention and respect.

\section{ACKNOWLEDGEMENTS}

I am grateful for the assistance of Paul Atkinson, Rabary Désiré, and Nestor Jean Randrianasy, without whom this work would not have been possible. I thank the staff of Marojejy National Park, particularly former Director Sylvain Vélomora, for their cooperation. Thanks are also due to several anonymous reviewers who made numerous constructive comments that improved this manuscript.

\section{REFERENCES}

Alphonse, M. 2004. Article sur l'exportation illicite de bois de rose : Rolly Mercia, convoqué à la gendarmerie. Madagascar Tribune July 92004

Alphonse, M. 2007. Exportation Illicite de bois de Rose. Madagascar Tribune $N^{\circ}$ 5472. Jan 29

Blundell, A.G. 2004. A review of the CITES listing of big-leaf mahogany. Oryx 38: $84-90$.

Blundell, A.G. 2007. Implementing CITES regulations for timber. Ecological Applications, 17: 323-330.

Brown, K.A. and Gurevitch, J. 2004. Long-term impacts of logging on forest diversity in Madagascar. Proceedings of the National Academy of Sciences, 101: 6045-6049.

Calvert, S. 2005. Vanilla's rise and fall takes Madagascar's growers for a ride. Baltimore Sun. December 10.

CITES. 1997. Tree species evaluation using the new CITES listing criteria. www.cites.org/eng/prog/criteria/1st_meetng/trees.shtml

Cochrane, M.A. and Schulze, M.D. 1998. Forest fires in the Brazilian Amazon. Conservation Biology, 12: 948-950.

Cocks, T. 2005. Loggers cut madagascan rainforest with impunity. Reuters. July 4.

Cowlishaw, G. and Dunbar, R. 2000. Primate Conservation Biology. The University of Chicago Press, Chicago, USA.

Du Puy, D.J. 2002. The Leguminosae of Madagascar. Royal Botanic Gardens, Kew, UK.

Duckworth, J.W., Evans, M.I., Hawkins, A.F.A., Safford, R.J., and Wilkinson, R.J. 1995. The lemurs of Marojejy Strict Nature Reserve, Madagascar:
A status overview with notes on ecology and threats. International Journal of Primatology, 16: 545-559.

Ganzhorn, J.U., Ganzhorn, A.W., Abraham, J.P., Andriamanarivo, L., and Ramananjatovo, A. 1990. The impact of selective logging on forest structure and tenrec populations in western Madagascar. Oecologia, 84: 126-133.

Garreau, J.M. and Manantsara, A. 2003. The protected-area complex of the Parc National de Marojejy and the Reserve Speciale d'AnjanaharibeSud. In: The Natural History of Madagascar, S.M. Goodman and J.P. Benstead (eds.), 1451-1458. University of Chicago Press, Chicago, USA.

Gillies, A.C.M. 1999. Genetic diversity in Mesoamerican populations of mahogany (Swietenia macrophylla), assessed using RAPDs. Heredity, 83: $722-732$.

Goodman, S.M. 2000. Description of the Parc National de Marojejy, Madagascar, and the 1996 Biological Inventory of the Reserve. Fieldiana Zoology, 97: 1-18.

Goodman, S.M., Hawkins, A.F.A., and Razafimahaimodison, J.C. 2000. Birds of the Parc National de Marojejy, Madagascar: With reference to elevational distribution. Fieldiana Zoology, 97: 175-200.

Humbert, H. 1955. Une merveille de la Nature à Madagascar. Première exploration botanique du massif du Marojejy et de ses satellites. Mémoires de I'Institut Scientific de Madagascar, série b, 6: 1-210.

IUCN, 2007. World heritage nomination. IUCN technical evaluation. Rainforests of the Atsinanana (Madagascar). IUCN Evaluation Report. ID No. 1257.

J.R. 2006. Trafic de bois de rose: Des dizaines de milliards en jeu. La Gazety. December 6, 2006.

Kett, G. 2005. Checking the reserve. Monthly from Madagascar. March. Madagascar Fauna Group.

Labat, J.N. and Moat, J. 2003. Leguminosae (Fabaceae). In: The Natural History of Madagascar, S.M. Goodman and J.P. Benstead (eds.), 346373. University of Chicago Press, Chicago, USA.

Martin, T. 2005. Ressources forestières - Le bois de rose interdit d'exportation. L'Express de Madagascar. February 21.

Musa, T. 2007. Chinese demand drives g/obal deforestation. Reuters. June 10. Nivo, T.A. 2007. Bois de rose : 800 isa no tratra tao amin'ny mpandraharaha iray. Madagascar Tribune. June 22.

Rakotondrainibe, F. 2000. Pteridophyte diversity patterns along an elevational gradient in the Parc National de Marojejy. Fieldiana Zoology, 97: 19-28.

Raoel, 2005. Trafic illicite de bois précieux. Madagascar Tribune. June 1.

Rasarely, E., Ramiandrarivo, L., Bettencourt, S., Bidani, B., Rajaonson, B., Rambeloarisoa, G. 2005. Mission report in the SAVA of November 21 to 24, 2005. World Bank Document.

Raselimanana, A.P., Raxworthy, C.J., and Nussbaum, R.A. et al. 2000. Herpetofaunal species diversity and elevational distribution within the Parc National de Marojejy, Madagascar. Fieldiana Zoology, 97: 157-174.

Rubel, A., Hatchwell, M., Mackinnon, J., and Ketterer, P. 2003. Masoala - L'oeil de la Forêt. Zoo Zurich.

Stephenson, P.J. 1993. The small mammal fauna of Reserve Speciale d'Analamazaotra, Madagascar: the effects of human disturbance on endemic species diversity. Biodiversity and Conservation, 2: 603-615.

US AID. 2005. Madagascar Annual Report FY 2005. June 16.

\section{EDITORIAL NOTE}

The author of this contribution could not fully satisfy the reviewers request to implement more witnesses of illegal logging, since it is very difficult to find people going on record.

Paul Atkinson, a Peace Corps Volunteer, received death threats after witnessing illegal logging activities in Marojejy National Park. As a result, the American Embassy decided to evacuate him in March 2006. Mr. Atkinson's Peace Corps tenure was due to end on April 7, 2006. 